\title{
Aggregate demand, employment and equilibrium with marginal productivity: Keynesian adjustment in the Craft Economy
}

\author{
Edward J. Nell \\ New School for Social Research, New York \\ e-mail: ejnell@aol.com
}

\begin{abstract}
Most Post-Keynesians have approached the idea that marginal productivity accounted for the demand for labor with scepticism. None of them have thought that supply and demand for labor determined employment and real wages. All agree that Keynes' approach recast the argument in money rather than real terms. But if the market operates with money wages, how exactly does the real wage adjust to the marginal product? If the real wage adjusts in the labor market, why is full employment not established? When there is unemployment in "equilibrium", why is it so deep and persistent? The argument will be that Keynes was thinking in terms of fluctuations in aggregate demand, and asking how a Marshallian economy would respond. Keynes can be interpreted as demonstrating that a multiplier is consistent with flexible prices based on profit-maximizing under diminishing returns so that the real wage equals the marginal product of labor. However, the Marshallian perspective has to be amended, as the economy moved towards Mass Production. In this paper, we will first examine the accepted account of the labor market, then go on to Marshallian technology and the price mechanism, showing how the economy would adjust to changes in aggregate demand. Then we will consider the consequences of a movement from a craft technology to Mass Production, and finally we will look at the Keynesian questions in fully developed Mass Production.
\end{abstract}

Key words : Keynes, economic theory, marginal productivity.

JEL classification: B22, E12, E24.

* Thanks are due to Stephen Kinsella for the elegant diagrams. 


\section{Introduction}

Most post-Keynesians have approached the idea that marginal productivity accounted for the demand for labor with caution and skepticism; some, like Paul Davidson and Victoria Chick, have accepted it with reservations. None of them, however, have thought that the account was illuminating or that supply and demand for labor determined employment and real wages. Ingrid Rima, for example, insists that the behavior of the labor market is chiefly determined by institutions, while Davidson and Chick have tried to accommodate Keynes' insistence that the real wage did equal the marginal product of labor, even in less than full employment equilibrium. All agree that Keynes' approach recast the argument in money rather than real terms, rejecting the Classical Dichotomy. But if the market operates with money wages, how exactly does the real wage adjust to the marginal product? If the real wage adjusts in the labor market, why is full employment not established? And when there is unemployment in 'equilibrium', why is it so deep and persistent?

Keynes asked why was there apparently stable, long-lasting involuntary unemployment, and why was there so much of it - why was the Depression so deep? He sought to develop the answers without completely overthrowing the framework of thought he had inherited. He repeatedly insisted that his argument proceeded to establish less-than-full employment equilibrium, “... without disputing the vital fact which classical economist have rightly asserted... that the real wage has a unique inverse correlation with the volume of employment... This is simply the obverse of the familiar proposition that industry is normally working subject to decreasing returns" (Keynes, 1936:17). Post-Keynesian interpreters contend that this implies that the marginal product curve shows positions of market equilibrium. ${ }^{1}$ This could be argued if prices generally were equal to marginal costs, as Keynes seems to have supposed (with marginal costs rising). A suggestion can be found in Keynes' Lectures. Starting from the expression giving employment as a function of expected sales proceeds, Keynes proceeds to derive an equation showing price equal to the wage bill times a markup expression divided by output (Rymes, 1989:137). Under competitive conditions (with appropriate

\footnotetext{
1 Both Davidson (1994) and Chick (1983) show how aggregate demand and aggregate supply in nominal terms interact (following Davidson and Smolensky) to determine employment and nominal output. Changes in money wages and prices will shift these aggregate functions, and a money wage-employment curve can be defined. But no process is defined showing how real wages and marginal productivity adjust.
} 
further assumptions) this would show price equal to or proportional to marginal cost, which would imply a corresponding relationship between the real wage and the marginal product of labor. But while a discrepancy between the real wage and the marginal product, under competitive conditions, can be considered a disequilibrium, how the market moves to correct this is not spelled out. It is necessary to show how the equilibrium can be reached by market processes, given that labor will respond only to money wages. This is not easy to find in the literature.

However, a simple diagram can help, though it will take some explaining. To develop it we will start from the assumption of given plant and equipment, operating under diminishing returns to additional employment of labor (what Robinson (1956) called a 'utilization function'). Initially we will take the money wage as given. But to explain in what sense, we will have to explore Keynes' conception of the labor market and marginal productivity.

In general the argument will be that Keynes was thinking in terms of fluctuations in aggregate demand, and asking how a Marshallian economy would respond. The claim here is that Keynes can be interpreted as demonstrating that a multiplier is consistent with flexible prices based on profit-maximizing under diminishing returns - so that the real wage equals the marginal product of labor. However the Marshallian perspective has to be amended, by reexamining the aggregate production function, and how it may have changed as the economy moved towards Mass Production.

First we will examine the accepted account of the labor market, then go on to Marshallian technology and the price mechanism, showing how the economy would adjust to changes in aggregate demand. Then we will consider simple changes in the production function as the economy moves from a craft technology to Mass Production, and finally we will look at the Keynesian questions in conditions of fully developed Mass Production.

\section{The marginalist account of the labor market}

When the General Theory was first published, many commentators, for example, Modigliani (1944) and Klein (1961), simply assumed that the marginalist account of the labor market was broadly accurate, provided wages and prices were flexible. But Keynes was correct, they argued, to note that, as a matter of fact, money wages (and prices) are often not flexible - for reasons which the early Keynesians did not explore very deeply. "New" Keynesians 
have since advanced an array of carefully developed theories to account for this -acknowledging and modeling imperfect markets and coordination failures (monopolies, oligopolies, unions, menu and transaction costs, bounded rationality), examining explicit and implicit labor market contracts, 'insider' markets and 'efficiency wage' systems, and exploring the effects of asymmetric risk aversion and asymmetric information in credit (and other) markets. Starting from utility maximizing households and profit maximizing firms, with Walrasian markets and the usual forms of rational economic calculation, New Keynesians have shown that introducing these plausible and largely realistic imperfections and limitations will result in price and wage rigidities that yield involuntary unemployment and other Keynesian conclusions.

In the light of history there is something very odd about this. In the late nineteenth and early twentieth century, both prices and money wages were flexible. That is, in response to variations in demand they both rose and fell, although prices were markedly more flexible in both directions than wages. (And both were more flexible than output and especially employment - with the result that higher levels of output and employment were statistically associated with lower real wages (Dunlop, 1938; Tarshis, 1939; for recent studies, Nell, 1998a; Nell, 1998b). Yet during this period, when prices and wages were flexible, virtually all the imperfections developed by New Keynesians and canvassed above were substantially more widespread and more severe, than in later periods when they are supposed to account for rigidity!

The standard Keynesian models take the money wage to be fixed, so that the system is in a kind of institutional disequilibrium the labor market cannot do its job, because there will be no proper labor supply function. Supply and demand do not operate as they normally would. Yet if that is so, it may seem unclear why the real wage should end up being equal to the marginal product of labor. All parts of the model interact, but what exactly brings the real wage and the marginal product to this position if the money wage cannot move? If the money wage is allowed to be flexible will that affect how marginal productivity adjusts? If wages are flexible there will be a labor supply function, so the market will work as it 'should'. This is the position taken for example by Modigliani. ${ }^{2}$

2 Modigliani and Hicks interpreted Keynes's premise that the real wage would equal the marginal product of labor as implying that employment would be determined in the labor market, unless that market were prevented from working by some kind of 
By contrast, Keynes' position -and that of most post-Keynesians - is that the starting point, the marginalist labor market, is simply not a correct account of wages and employment. The employment of labor and the setting of wages are not brought about through the functioning of a market in the marginalist sense - that is, a market in which the wage reflects productivity at the margin on the one hand, and the disutility of additional effort on the other. In such a market, in which behavior is governed by costs on both sides, we might expect effort to be allocated optimally, if other appropriate conditions are met; to define such a market, to serve as the norm or standard, is presumably the neo-classical project. But, according to Keynes, the labor market does not and cannot function that way. The wage, he argues, does indeed reflect the marginal productivity of labor, but it does not and cannot reflect its marginal disutility. There is no adjustment mechanism, no way that the real wage could be brought into alignment with the marginal disutility of labor. Labor could accept or reject a money wage; but they could do nothing about prices, nor could they reliably know whether prices would be stable or changing in the near future. ${ }^{3}$

Keynes objected not only to the marginalist labor supply function, but most importantly to the idea that employment and real wages (and so output) were determined in the labor market. Labor supply depends on people needing jobs, and can be taken, in the short run, as an institutional datum, influenced to changing degrees by many factors. Money wages may have an influence; so may prices. So may the availability of jobs. These factors may be affected in unpredictable ways by non-economic matters. The labor market will influence only money wages, while the product market will affect

'imperfection'. The claim here is that Keynes can be understood quite differently; it is consistent with his argument that prices could adjust relative to money wages, in order to bring the real wage into alignment with productivity at the margin. In this case there would be no 'labor market' of the traditional type, but as we shall see such a system of price adjustment will tend to provide stabilization (however - a point that Keynes certainly did not see - such a tendency to stabilize will be eroded as technology develops, since technological improvement will provide business with a greater ability to adjust employment and output to the variations in demand).

3 Keynes always distinguished wage movements from price movements; wages and prices responded to different market pressures, so could adjust separately. Of course, they would also influence each other. But even over long periods they could move differently; accordingly, in the Treatise, he distinguished wage inflation and profit inflation. 
prices, and adjustment will take place through the interaction of all parts.

In short, he argues that a marginal product curve can be defined, but not a supply curve based on relating disutility of labor to the real wage. Yet he does not explain how the real wage is brought and kept equal to the marginal product. Nevertheless, he argues that the economy will tend to equilibrium, in the sense that the real wage will equal the marginal product of labor, thus maximizing profits, even though the economy typically reaches a position of less than full employment. Most significantly, he argues that fluctuations due to changes in investment spending will be amplified - consumption will move in the same direction as investment. How can these points all be brought together? To what extent do they depend on relating behavior and choice to money variables, rejecting the Classical Dichotomy?

The argument here will be an extension of the Keynesian position, starting from the idea that the labor market works differently under different technologies, because costs are different. The suggestion here is that technology governs the behavior of costs, and that the behavior of costs determines whether and to what extent prices and wages are flexible - and, indeed, may generate market incentives to change that flexibility. A brief sketch outlining this view might help.

Two technologies will be considered, one which can be labeled "Craft-based" or "Marshallian", in which small enterprises employ skilled work teams, and in which it is difficult and costly to vary output or employment. The other is Mass Production, in which output and employment are easily and rapidly adjusted to variations in sales, and variable costs tend to be constant over a wide range of output levels. We will argue that neither allows for a labor market in which there will be an adjustment process that would tend to move the system towards a position in which all labor seeking jobs will find employment at a determinate wage.

In what follows we will first explore the adjustment of employment and wages in the Craft or Marshallian Economy, and then consider adjustment in a Mass Production system.

We start with a Marshallian technology showing clear diminishing returns to employing additional labor with given plant and equipment. But this is an unsatisfactory technology, and firms will try to gain greater control over costs, leading eventually to a 'flattening' of the employment-output function, until it becomes a straight line, indicating constant returns. In the Marshallian economy 
both wages and prices are flexible, but prices are more flexible than wages - the proportional deviations are greater - and both fluctuate more than employment. This is because production is based on a technology of skilled craft workers; production teams must work together; their ability to function together is part of the 'embodied' capital of the firm - breaking them up will be a capital loss. Plus start-up and shutdown costs are high. Hence only inessential workers can be laid off. Thus demand fluctuations will be met by slowing down production somewhat, but not reducing employment much. Profits will bear much of the burden of slower sales, providing an incentive to firms to gain better control over their costs. This they will do by increasing their capital investment and mechanizing. This will make it possible to vary output and employment together over a range, with unit running costs staying constant.

\section{A model with Marshallian technology and Keynesian wages}

We can write a set of equations related to traditional interpretations, e.g. Modigliani's system, but which, arguably, will be closer to Keynes (See Nell, 1998a: Ch. 12, part I). In this interpretation of Keynes the behavioral equations are written in real terms, so there is no possibility of money illusion. Furthermore, while the real wage is equal to the marginal product of labor in general, the real wage and employment are not determined in the labor market. They emerge from the entire system (Keynes, 1936: Ch. 2; Rymes, $1989 ; 4,6)^{4}$. Instead prices and demand are determined in the product markets, and employment adjusts to demand. Two cases are considered: in the first, money wages are given, in the second they are influenced by the level of employment in relation to full employment.

$$
\begin{aligned}
& \mathrm{Y}=\mathrm{Y}\left(\mathrm{N}, \mathrm{K}^{*}\right) \\
& \mathrm{w} / \pi=\delta \mathrm{Y} / \delta \mathrm{N}=\mathrm{Y}^{\prime}(\mathrm{N}) \\
& \mathrm{C}=(\mathrm{w} / \pi) \mathrm{N} \\
& \mathrm{I}=\mathrm{I}(\mathrm{i}, \mathrm{C}), \mathrm{I}_{\mathrm{i}}<0, \mathrm{I}_{\mathrm{C}}>0 \\
& \mathrm{M} / \pi=\mathrm{L}(\mathrm{i}, \mathrm{Y}), \mathrm{L}_{\mathrm{i}}<0, \mathrm{~L}_{\mathrm{Y}}>0 \\
& \mathrm{Y}=\mathrm{C}+\mathrm{I} \\
& \mathrm{Y}=(\mathrm{w} / \pi) \mathrm{N}+\mathrm{P}
\end{aligned}
$$

4 Rymes (1989) is a reconstruction of Keynes' lectures based on notes taken by those attending, many of whom became distinguished economists later. The lectures show how he was struggling to develop an analysis of the way employment and output could vary, consistently with at least a good part of the established framework of thought. 
The notation is pretty standard: Y, C, I and P are output, consumption, investment and profits, in real terms. $\mathrm{N}$ is employment. $\mathrm{M}, \mathrm{w}$, and $\pi$ are money, money wages and the price level, all in money terms. The rate of interest is i. Eq. 1 is the short-run production function, with diminishing marginal products, Eq. 2 equates the real wage with the marginal product of labor, Eq. 3 states that aggregate consumption equals the wage bill (the classical savings function), Eq. 4 is a Keynesian investment function and Eq. 5 is Liquidity Preference. Then Eqs. 6 and 7 define expenditure and income ${ }^{5}$. We then have two possibilities for closing the model:

$$
\begin{aligned}
& \mathrm{w}=\mathrm{w}^{*}, \quad \mathrm{w}^{*} \text { is rigid or fixed } \\
& \mathrm{w}=\mathrm{w}-\mathrm{w}^{*}=\mathrm{F}\left(\mathrm{N}-\mathrm{N}^{*}\right)
\end{aligned}
$$

where $\mathrm{w}^{*}$ is the normal or initial level, and $\mathrm{N}^{*}$ is full employment (neither Modigliani nor Hicks even consider the possibility of an equation like Eq. 8b, yet it seems to be suggested by Keynes' discussion of money wages and prices).

A thought experiment will shed some light on the idea of flexible money wages and prices: substitute the above Eq. $8 \mathrm{~b}$ for the Eq. 8a in this model. The lower money wage will require a lower price level to sustain the same real wage. But $\mathrm{M}$ is fixed; with lower prices, there will be lower transactions demand, requiring a lower rate of interest to absorb the money supply. The lower rate of interest will mean higher investment demand, implying higher $\mathrm{N}$, and a lower real wage, with the effect on consumption depending (as we shall see) on the elasticity of the marginal product curve. This is to some extent offsetting - there is no reason to think that a decline in money wages proportional to unemployment would lower transactions demand, and so the interest rate, enough to generate the investment demand needed to move to full employment, especially if it has to offset reduced consumption spending.

Perfectly flexible money wages, on the other hand, would be different. In that case, a small amount of unemployment would bring about an indefinitely large decline in money wages. In that purely artificial case - if prices followed suit immediately so that the real wage is unchanged - then the transactions demand would fall towards zero, bringing the rate of interest down to the liquidity trap level. Then, depending on the elasticity of I with respect to interest, the

\footnotetext{
${ }^{5}$ Eq. 6 may be considered an equilibrium condition, but Eq. 7 is best interpreted as an identity: output has to equal income (everything produced must be owned, or covered by a claim.)
} 
economy might tend towards full employment. But the idea of perfect price/wage flexibility is not just unrealistic; it is evidently inconsistent with the widespread use of forward money contracts. Such contracts, designed to reduce uncertainty, are a fundamental aspect of a monetary economy - a point Keynes emphasized, as Davidson reminds us. But moderately flexible money wages will not necessarily move the economy towards full employment, as we shall see.

To show this we need a reasonable account of how market pressures drive the adjustment to the point where the real wage equals the marginal product of labor. Keynes does not provide this, but we will construct an argument that is consistent with his assumptions and approach. On this basis we can justify his claim that there may be many possible equilibrium positions, that all but one of these will be at less than full employment, and that flexible money wages will not move the system to full employment. Keynes assumed aggregate diminishing returns; accordingly we assume that the technology is "Marshallian", that is, that craft labor can be applied to given equipment in the short run, resulting in diminishing returns, as in Marshall's account.

\section{The price mechanism and Marshallian technology ${ }^{6}$}

The principles underlying the Craft Economy center on the short-run employment-output relationship ${ }^{7}$. In the Craft Economy (Nell, 1998a; Nell, 1998b), we can reasonably assume diminishing returns to the employment of labor, in relation to a normal position. Adding extra workers to work teams operating given equipment

${ }^{6}$ Early capitalism, through the nineteenth century, appears to have had a weak built-in automatic stabilizer in a 'price mechanism', which depended on technological inflexibility, and moved countercyclically, in tandem with the monetary system. This was swept away with the advent of mass production, and replaced by a volatile pattern of adjustment, in the multiplier augmented by the accelerator (or capital-stock adjustment process), so that the system came to rely on government for stabilization. This has explored for six countries, the US, the UK, Canada, Germany, Japan and Argentina, in which adjustment during the period 1870-1914 is contrasted with that in 1950-1990. Evidence of a weakly stabilizing price mechanism is found in all six in the early period; the transition to a multiplier-based adjustment is apparent in all but Argentina, which did not seem to fully accomplish the transition to a modern economy during the period studied (Nell, 1998b).

${ }^{7}$ This is a short-run relationship in which given plant and equipment is operated with more or less labor. Marshall and Pigou arguably operated with such a conception, (Hicks, 1989). A 'true' production function would require changing the technique when the amount of labor per unit capital varied (Hicks, 1963). This is not a viable conception, as the 'capital controversies' showed (Kurz and Salvadori, 1995; Laibman and Nell, 1977). 
brings progressively lower rewards, while removing workers leads to progressively larger losses of output. In general, it will be difficult to adjust levels of employment. Workers cooperate in teams that cannot be lightly broken apart or added to; all workers have to be present and working for a process to be operated at all; processes cannot easily be started up and shut down. So the Craft Economy not only has diminishing returns, it also has inflexible employment (Nell, 1998a, Ch. 9) ${ }^{8}$.

Our model is based on such an aggregate function, given as Eq. 1 above, where we have assumed a conventional shape and properties. This is appropriate for a Craft Economy ${ }^{9}$ where output increases with labor according to a curved line that rises from the origin with a diminishing slope (by contrast, Mass Production will be characterized by a straight line rising from the origin $\left.{ }^{10}\right)$. As a first approximation Consumption can be identified with wages and salaries ${ }^{11}$, while for the purpose of drawing the diagram Investment can be taken as exogenous. As employment rises, the wage bill - and so

8 In post-war Mass Production (Nell, 1988a; 1998b), by contrast, constant returns prevail in the short run; to put it differently, unit costs are broadly constant. Workers need only be semi-skilled and teams can easily be broken up and re-formed; processes can be operated at varying levels of intensity in response to variations in demand, and they can easily be shut down and started up. It is likewise easy to layoff and recall workers. The widespread existence of constant unit costs came to light beginning with the debate on prices and pricing in the 1930s and 1940s, cf. Hall and Hitch, 1938; Andrews, 1949; 1964. The suggestion here is that constant costs were the result of technological developments in manufacturing processes (Hunter, 1979; 1985). The evidence for constant costs is summarized and discussed in Lavoie (1994: Ch. 3). Under constant costs, of course, the real wage will not be governed by marginal productivity.

9 To move from individual firms to the aggregate it is not necessary to hold the composition of output constant, so long as the movements are small. In both Craft and Mass Production the adjustment is better shown in two sectors. The aggregate function oversimplifies. When proportions of capital to consumer goods change in the Craft world, prices change; when they change in Mass Production the degree of utilization changes, but unit costs and prices are not affected.

${ }^{10}$ The Penn World Tables provide data making it possible to plot output per head against capital per head with a large number of observations. When this is done for the advanced OECD economies, the scatter diagram shows no evidence of curvature. The same plot for the backward economies exhibits pronounced curvature, for middle range economies moderate curvature. Of course this can be considered no more than suggestive.

${ }^{11}$ Wages and salaries in the aggregate are closely correlated with Consumption spending, but do not fully explain it. Some obvious adjustments are easily made. Consumer spending also depends on the terms and availability of consumer credit. In addition it reflects transfer payments. Wealth and profitability are significant variables. But for the present purposes, which are purely illustrative, a simple 'absolute income' theory will suffice. 
Consumption spending - will rise at a constant rate, namely the normal wage rate. Total expenditure will then be shown by adding Investment to the wage-consumption line.

The diagram presents the aggregate utilization function, with output on the vertical axis and labor employed on the horizontal. The function of the Craft Economy is curved, its slope falling as $\mathrm{N}$ increases (the Mass Production line would rise to the right with a constant slope). The wage bill (including salaries) will be assumed to be equal to Consumption spending (transfer payments could be included also). No household saving and no consumption out of profits - but both assumptions are easily modified. ${ }^{12}$ So the wage bill, also representing consumption spending, is shown by a straight line rising to the right from the origin; its angle is the wage rate. Investment spending will be treated as exogenous in the short run, so will be marked off on the vertical axis. Aggregate demand will then be the line $\mathrm{C}+\mathrm{I}$, rising to the right from the I point on the vertical axis; its slope is the wage rate.

\section{Adjustment to demand fluctuations in the Craft Economy}

Suppose Investment is unusually low, below normal, so that this line cuts the utilization function at a point below the normal level of output and employment, $\mathrm{N}^{\prime}$. Since it is difficult to adjust employment and output, there will tend to be overproduction, and prices will fall. Since it is even harder to adjust employment than output, prices will fall more readily than money wages. Hence the real wage will rise, from $w_{0}$ to $w_{1}$, (expressing the real wage in italics here). As a result the $\mathrm{C}+\mathrm{I}$ line will swing upwards, until it is tangent to the utilization function; employment thus settles not at $\mathrm{N}_{1}{ }_{1}$ but at $\mathrm{N}_{1}$. Notice that this point of tangency will tend to be close to the normal level of employment and output, and will be closer the more concave the function. In short, when Investment is abnormally low, the real wage will rise; if the rise in real wages is proportionally greater than the decline in employment Consumption will increase. This is the case illustrated in the diagram; investment falls from $\mathrm{I}_{0}$ to $\mathrm{I}_{1}$, prices fall and

\footnotetext{
${ }^{12}$ This, of course, directly contradicts one of Modigliani's most celebrated contributions, the life cycle hypothesis. But half a century of empirical evidence has shown that in the U.S. (and other advanced countries) household consumption spending tracks wage and salary income 'too closely' for any simple version of the life cycle hypothesis to be correct (Deaton, 1992).
} 
the real wage rises. Clearly the wage bill, and so consumption, is higher at $\mathrm{N}_{1}$ than at $\mathrm{N}_{0}$.

\section{Figure 1}

Adjustment in the Craft Economy

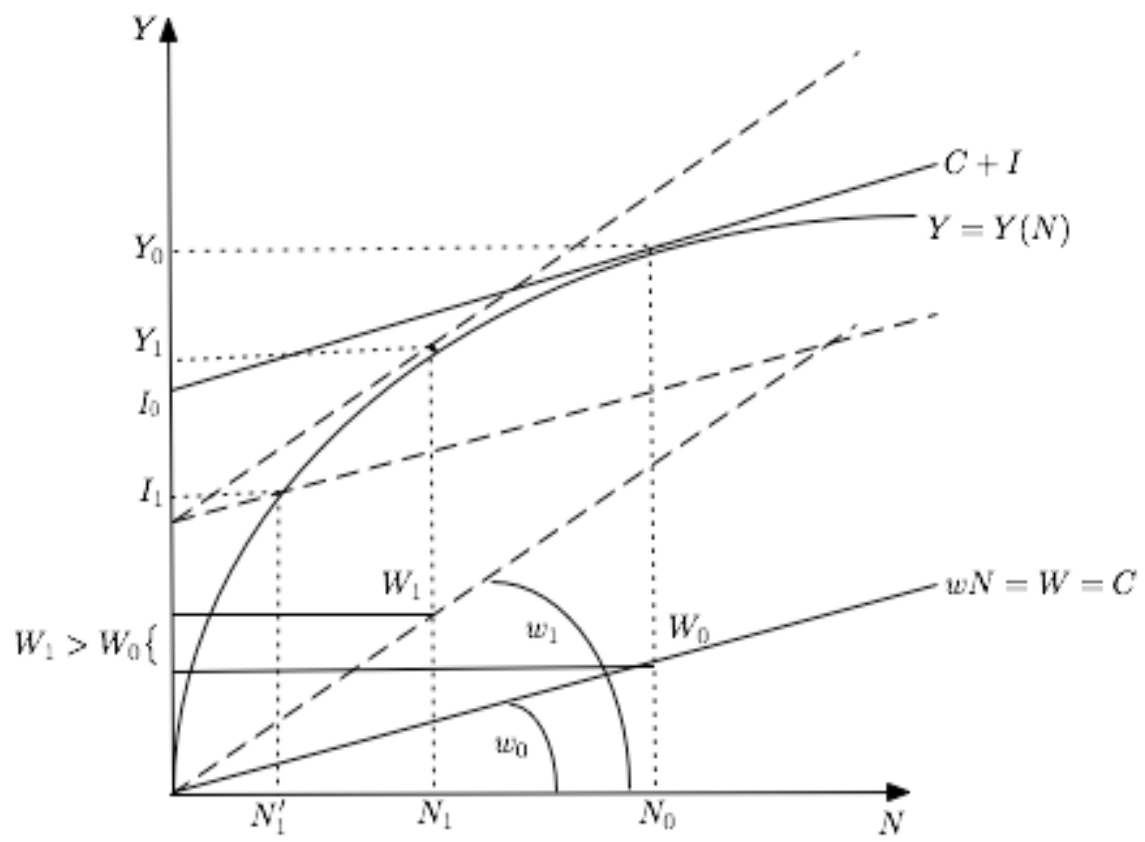

Conversely, suppose Investment were exceptionally high, or that the $\mathrm{C}+\mathrm{I}$ line had too steep a slope, indicating too high a real wage. In either case, expenditure would lie above output at any feasible level of employment. Under these conditions prices would be bid up relative to money wages, and the $\mathrm{C}+\mathrm{I}$ line would swing down, until it came to rest on the utilization function in a point of tangency. (Nell, 1998a: 455-7) Again this point would tend to lie close to the normal level, being closer the more concave the function. When Investment is unusually high, Consumption will tend to adjust downwards.

Notice that adjusting the real wage to equal the marginal product of labor both assures a unique equilibrium and maximizes profit. ${ }^{13}$ When the $\mathrm{C}+\mathrm{I}$ line is tangent to the utilization curve the distance to the

\footnotetext{
${ }^{13}$ Nothing is implied in this discussion about the marginal product of capital. Since capital is given in amount and fixed in form, no change is possible, and its marginal product is not defined.
} 
wage line is at a maximum; if $\mathrm{C}+\mathrm{I}$ cuts the utilization curve, there will be two equilibria and the distance between the intersection points and the wage line will be less than that at the tangency. (Given the real wage, profit rises with employment at a diminishing rate from the origin to the tangency point; it then falls at an increasing rate until it reaches zero at the point where the production function intersects the wage line.)

Figure 2

Behavior of Profits

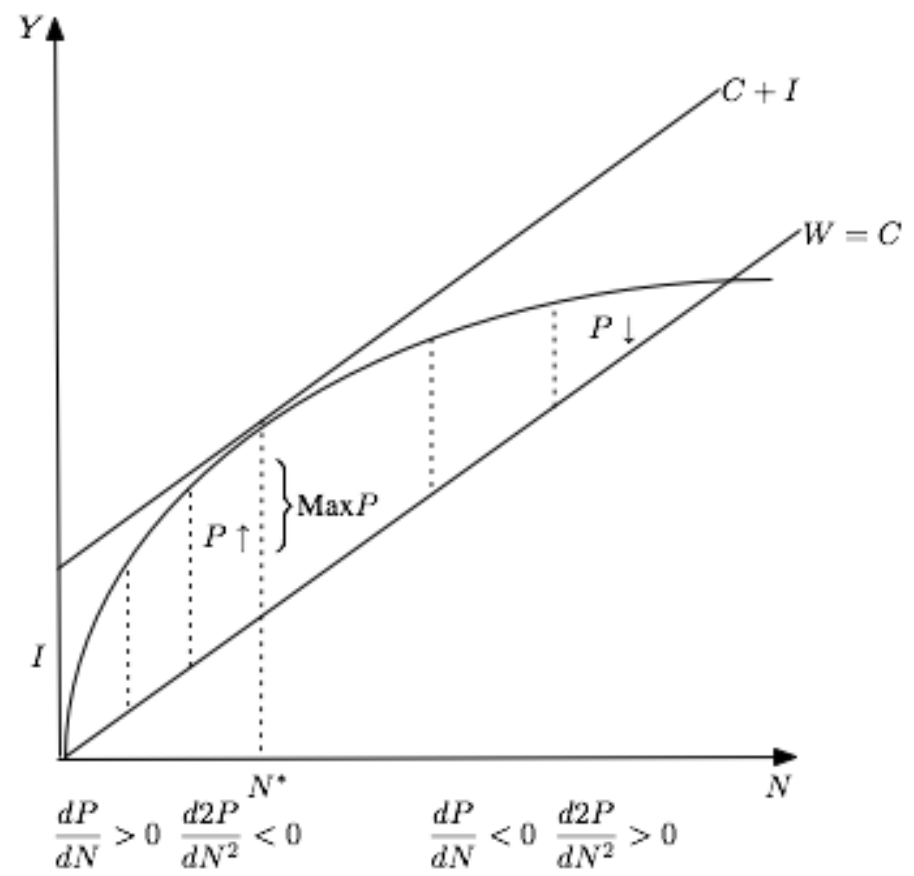

We need to define the point of full employment - at which the entire labor force has jobs. An appropriate concept of full employment would be 'no vacancies' or, rather, 'no vacancies except turnover vacancies'. Employment is full when all farms, factories, offices and shops have hired the employees they need to operate at their optimal level. Output at the point of full employment will be associated with a marginal product; that marginal product will become a real wage, which multiplied by the level of full employment defines the wage bill, equal, ex hypothesi, to consumption. The difference between full employment output and consumption must be filled by investment. 
Now let investment fall below this full employment level. As it does, it will trace out the marginal product curve; at each lower level of investment, prices will fall, and the real wage rise, while employment falls; the overall effect on consumption will depend on the elasticity of the marginal product curve. But each point on the curve will be an equilibrium, in the sense that money wages and prices have adjusted to produce the profit maximizing position.

That this pattern of price flexibility dampens fluctuations by partially offsetting them, in conditions of strongly diminishing returns, can be shown very simply. Recalling our equations: $\mathrm{Y}$ is real output, $\mathrm{N}$ employment, w/ $\pi$ the real wage, and I investment. All wages are consumed. As above,

$$
\begin{aligned}
& \mathrm{Y}=\mathrm{Y}(\mathrm{N}), \mathrm{Y}^{\prime}>0, \mathrm{Y}^{\prime \prime}<0 \\
& \mathrm{Y}=\mathrm{C}+\mathrm{I} \\
& \mathrm{w} / \pi=\mathrm{Y}^{\prime}(\mathrm{N}) \\
& \mathrm{C}=(\mathrm{w} / \pi) \mathrm{N} \\
& \mathrm{Y}=\mathrm{I}+(\mathrm{w} / \pi) \mathrm{N}, \text { so } \\
& \quad \begin{aligned}
\mathrm{d} / \mathrm{dI} & =\delta \mathrm{I} / \delta \mathrm{I}+\mathrm{N}[\delta(\mathrm{w} / \pi) / \delta \mathrm{I}] \\
& +(\mathrm{w} / \pi)[\delta \mathrm{N} / \delta \mathrm{I}]=1+\mathrm{N}[\delta(\mathrm{w} / \pi) / \delta \mathrm{I}]+(\mathrm{w} / \pi)[\delta \mathrm{N} / \delta \mathrm{I}]
\end{aligned}
\end{aligned}
$$

Clearly

where $\mathrm{N}[\delta(\mathrm{w} / \pi) / \delta \mathrm{I}]<0$ and $(\mathrm{w} / \pi)[\delta \mathrm{N} / \delta \mathrm{I}]>0$. So $\mathrm{dY} / \mathrm{dI}$ is greater or less than unity, according to whether $\mathrm{N}[\delta(\mathrm{w} / \pi) / \delta \mathrm{I}]$ is greater or less than $(\mathrm{w} / \pi)[\delta \mathrm{N} / \delta \mathrm{I}] .^{14}$ So long as returns diminish sufficiently $\mathrm{dY} / \mathrm{dI}<$ 1 ; price changes due to variations in investment demand will lead to a partial offset. $^{15}$

In short, so long as diminishing returns are significant the price mechanism will lead Consumption to adjust so that it will tend to make up for a shortfall or offset an excess of Investment. It thus tends

\footnotetext{
${ }^{14}$ It is tempting to set the model out in the form $\mathrm{Y}=\mathrm{AN}^{\alpha}$, so that $\mathrm{w} / \pi=\alpha \mathrm{AN}^{\alpha-1}$. Then $\alpha$ becomes the parameter governing the rate at which returns diminish. However, the power function is only one of several forms that the relationship between $\mathrm{Y}$ and $\mathrm{N}$ might take. In particular the log form will be important.

${ }^{15}$ Rymes (1989: 37-8) suggests that the real argument of the "Manifesto" by Robinson and Kahn concerned this effect. Rymes argues "If the increase in investment ... results in a sufficient increase in demand, not only a higher price but also an increase in the costs of production facing the entrepreneur in the consumption goods sector, such that the new equilibrium... entails a higher outlay on consumption goods, then it is possible the decline in the output of consumption goods could, in terms of effects on the volume of employment, more than offset the increase in the output of capital goods." Investment increases and consumption declines.
} 
to stabilize demand around the normal level of output and employment.

This form of adjustment brings to mind the doctrine of 'forced saving' (Thornton, 1802; Hayek, 1932; Robertson, 1931). Here, however, the price changes are assumed to reflect changes in demand pressure -not necessarily connected to changes in the quantity of money -and are shown to result in a Marshallian 'marginal productivity' equilibrium ${ }^{16}$. The traditional 'forced saving' discussion usually started from an assumed increase in the money issue or in an exceptional extension of credit, and, indeed, a rise in demand of the kind considered here would require just such additional finance which the resulting rise in prices relative to money wages would tend to support. The higher profits will allow banks to charge higher interest rates, enabling them to attract additional reserves. The higher interest rates, however, should tend to dampen further expansion. ${ }^{17}$

This shows that there is good reason to expect adjustment to bring about a real wage and a level of employment, such that the real wage will be equal to the marginal product of that level of employment - which need not be full employment. So let's return to model and work through it - starting with the solution when we have a fixed money wage. An instructive informal approach: set the Investment function equal to profits, in effect setting out an analogue to the conventional IS curve. This combines Eqs. 4, 6 and 7 with Eqs. 1,2 and 3, yielding a relationship between $\mathrm{i}$ and $\mathrm{N}$, based on the equality of I and P. Then Eq. 5 can be combined with Eqs. 1 and 2, to form another function relating $\mathrm{i}$ and $\mathrm{N}$, based on the equality of $\mathrm{M}$ and liquidity demand. But since Eq. 2 is drawn on in constructing both, Eq. 8a must be used to set the money wage at the fixed level. Then these two relationships can be solved for $\mathrm{i}$ and $\mathrm{N}$, and the results (which will depend on the form of the functions ${ }^{18}$ ) substituted back to

16 "Forced saving" was traditionally ascribed to the effects of an exceptional increase in the quantity of money, leading to a bidding up of prices, lowering consumption and so making an expansion of investment possible. One issue was whether the resulting increase in capital was permanent or temporary; another concerned the effect of the higher prices on rentiers. How the money supply was increased also became an issue, as did the relationship to interest rates (see also Malthus, 1823; Ricardo, 1811; and Keynes, 1940; as well as those cited above).

${ }^{17}$ But the process cannot continue for too long, for with I rising and $\mathrm{C}$ falling, the ratio of capital goods to consumer goods will be moving further and further from its normal level (see Nell, 1998: 458-9). However, the monetary/credit system may support prices for too long, "overshooting" provoking a sharp crash.

${ }^{18}$ Linear functions and plausible relations between parameters appear to provide unique positive solutions. 
establish the equilibrium values of the other variables. All the markets interact, but there is no reason to expect full employment.

Now let us turn to the second case, replacing the fixed wage equation with flexible money wages, Eq. 8b. This states that when there is unemployment money wages will fall, with the decline proportional to the rate of unemployment. Given that unemployment reflects lower demand, we can expect that prices will also fall, but prices will have to fall further, in order for the wage bill to rise enough for there to be an offset to the lower demand. If there is no offset then the fall in money wages could reduce the real wage, and make unemployment worse than if money wages had been rigid.

Next we propose to deal more fully with the financial market by allowing for arbitrage between equity and bonds. The ModiglianiMiller Theorem argues that arbitrage ensures that bonds and equity are perfect substitutes. The proposal here is much less extreme; it just asserts that there will be market pressures to pull the current rate of profit and the rate of interest together, in circumstances where the Central Bank is not pegging.

$$
\mathrm{P} / \mathrm{K}=[\mathrm{Y}-(\mathrm{w} / \pi) \mathrm{N}] / \mathrm{K}=\varepsilon \mathrm{i},
$$

where $\varepsilon$ is a parameter representing risk and the 'equity premium'.

This has the effect of fixing the interest rate, but because we have dropped Eq. 8a, it leaves the money wage as a variable, although we have not specified an equation to govern it. It will simply be determined as a residual - for the moment. The result is quite striking: a version of the Classical Dichotomy reappears - but there is no reason to expect full employment.

An informal argument can support this as follows: Start with Eq. 4 , the investment equation,

$$
\mathrm{I}=\mathrm{I}(\mathrm{i}, \mathrm{C})
$$

and eliminate $\mathrm{i}$ and $\mathrm{C}$ on the RHS, by substituting into it, using the production function, Eq. 1, the real wage equation, Eq. 2, consumption, Eq. 3, and the income equation, Eq. 7. In this way eliminate the other variables until only $\mathrm{N}$ and coefficients remain. Note that to remove the interest rate, i, Eq. $8 \mathrm{c}$ will have to be used (when the model rested on $8 \mathrm{a}$, fixed wages, the interest rate could not be removed from the investment equation, Eq. 4, without drawing on the monetary equation, Eq. 5; monetary and real parts of the economy interact). Next use equation $\mathrm{Y}=\mathrm{C}+\mathrm{I}$ to replace I on the LHS, and then draw on Eqs. 1, 2, and 3 to reduce every expression to a function of N. Then solve for N, and substitute back. From Eq. 1, we find Y; 
from Eq. 2, w/ $\pi$; from Eq. 3, C; from Eq. 6, I. Then with I and C, the interest rate, i, will follow from Eq. 4. Finally, Eq. 8c yields P, profits. Thus the seven equations pertaining to Savings-Investment and Output-Employment determine the seven real variables:

$\mathrm{N}, \mathrm{Y}, \mathrm{C}, \mathrm{I}, \mathrm{P}, \mathrm{i}$, and $\mathrm{w} / \pi$.

Eq. 5 , for the money market, is left to determine $\pi$, the price level, which will then give us the money wage from Eq. 2. So real relationships determine real variables and monetary forces affect only nominal variables!

But to leave the money wage simply drifting, determined residually, cannot be allowed, given the intense market (and nonmarket!) pressures on money wages. However, we can turn to Eq. 8b which models the pressures on the money wage. Yet adding this equation, too, would appear to overdetermine the model. The natural response would be to allow for a flexible money supply -so that $\mathrm{M}$ becomes a variable that will adapt to the pressures of the market. This can be allowed to drift, for that simply says that the authorities will accommodate. Thus a version of the Classical Dichotomy can be derived, with the real wage equal to the marginal product of labor, although the model is demand-driven, and need not reach equilibrium at full employment. ${ }^{19}$

The importance of money here lies in the fact that wages are paid in money, and prices charged in money. Labor never faces real wages in the market; it can only react to the money wage, which means that supply and demand in the labor market cannot determine employment and the real wage, as mainstream economics has held. The mainstream system pretended that markets adjusted in response to real variables, whereas in fact adjustments necessarily take place in response to money variables. Worse, the traditional approach assumed that the economy always operated at full employment. This was unjustified.

But rejecting the Classical Dichotomy by itself did not explain either unemployment or why the Depression was so severe. Equilibrium was possible at less than full employment because employment was determined by aggregate demand, not in the labor market. But this still did not explain why the Depression was so deep. That only became clear with the understanding that changes in

\footnotetext{
${ }^{19}$ We can study these equations by writing them out with a Cobb-Douglas production function and linear coefficients in the other functions; the procedure for solution is simple. This will show that there is no partitioning of the model.
} 
investment led to changes in consumption in the same direction - the idea behind the multiplier. When investment fell, consumption also fell. This was why the fluctuations were so serious. And this is consistent with the real wage adjusting to equal the marginal product of labor - so there is a profit-maximizing equilibrium, one among many possible, even though full employment may not be reached and the swings may be severe.

We can explain this in another way, drawing on the changes in the production function. When the curvature of the production function is considerable, the elasticity of the marginal product curve will be greater than -1, so a fall in investment will lead to a rise in the wage bill and therefore in consumption spending, as shown in the diagram. But when the production function is rather flat, the elasticity of the marginal product curve will be less than -1 , so that a fall in investment will lead to a decrease in the wage bill and consumption spending, as indicated. In this case there is not only no offset to the drop in investment - the effects are actually made worse. And that is the conclusion Keynes reached and tried to explain in the lectures he gave in Cambridge.

The variability of profits provides an incentive to change the technology so as to control current costs; the innovations must change current costs from fixed to variable; this will be done by increasing capital costs. Consider a Samuelson surrogate production function, with pressures for $w$ to increase- at the higher wage it is worthwhile to mechanize, so in current prices capital per worker rises, and the scale effects allow for greater flexibility in adjusting employment to changes in the level of demand.

\section{The multiplier replaces the Price Mechanism}

Fluctuations in I will normally have some impact on $\mathrm{N}$ even in a Craft Economy. But there will be an offsetting movement in $\mathrm{C}$ so long as the curvature of the employment function is large. The price mechanism is stabilizing for the system as whole, but the effect is that profits fluctuate sharply for individual businesses. So firms will be motivated to redesign their production systems to allow greater flexibility in adapting to demand fluctuations. This means being able to add on or layoff workers, without greatly disturbing unit costs. As such redesigning takes place, it will reduce the curvature of the employment function; that is, diminishing returns will be lessened. We can think of this as a progressive 'flattening' of the employment function. When this has reached the point where the marginal product 
curve has unitary elasticity, so that the proportional change in the real wage is just matched by that in employment, then the total wage bill is unaffected by the price changes following the change in I. If the total wage bill is unaffected, then, on the assumptions made earlier, total $\mathrm{C}$ will be unchanged.

This will be the case, for example, when the employment function takes the form: $\mathrm{Y}=\mathrm{A}(\ln \mathrm{N})$. Hence I may fall, for example, but $\mathrm{C}$ will not change. There will be no offset. So $\mathrm{dY} / \mathrm{dI}=1$. Any further reduction in the rate at which returns diminish will mean that the change in employment will outweigh the change in the wage bill, so that $\mathrm{C}$ will move in the same direction as I. In this event, $\mathrm{dY} / \mathrm{dI}>1$ will always hold (Nell, 1992; 1998a; Nell and Deleplace, 1992).

\section{Figure 3}

Consumption Moves with Investment

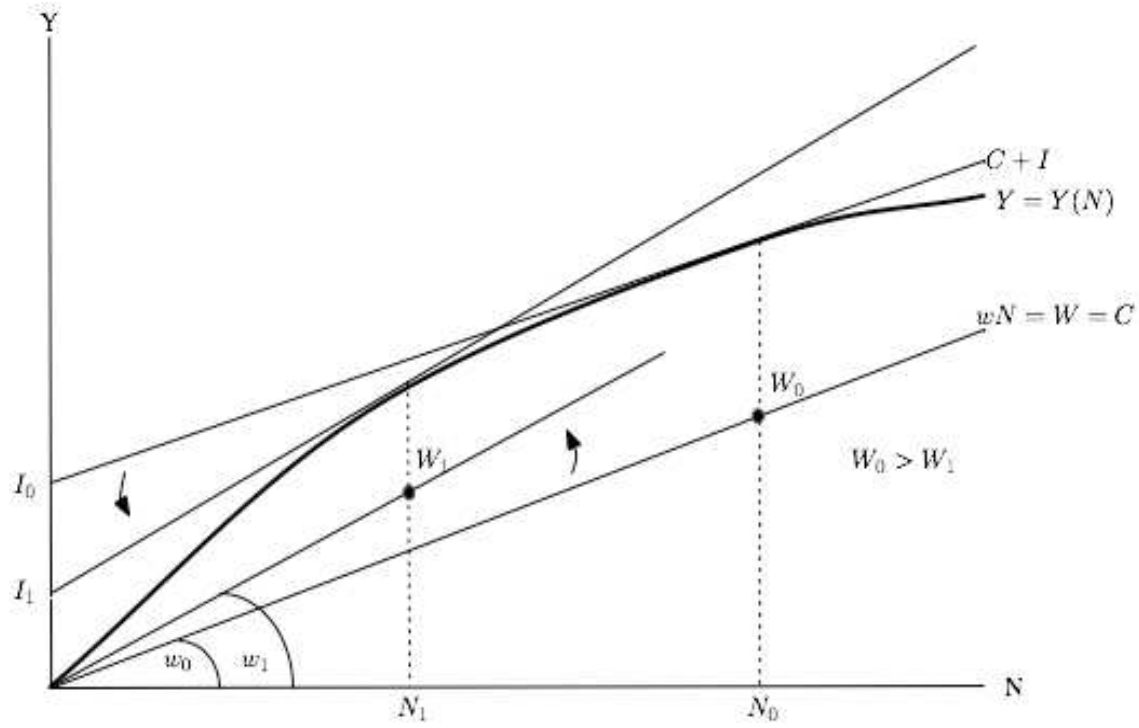

It can be argued that this was the conclusion that Keynes seems to have been seeking. In his Second Lecture in the Easter Term, 1932, Keynes reached "... the remarkable generalization that, in all ordinary circumstances, the volume of employment depends on the volume of investment, and that anything which increases or decreases the latter will increase or decrease the former" (Keynes, 1972-9: Vol XXIX, p. 40; see also Rymes, 1989: 30-44). The "Manifesto" written by Joan Robinson and Richard Kahn, with the concurrence of Austin Robinson, challenged not the result, but the reasoning used in reaching it (see Keynes, 1972-9, vol. XIII, pp. 376-7; vol XXIX, p. 47; Rymes, 
1989: 38-41). As noted above, part of their discussion concerned the effects of price changes on demand. Rymes notes, "The 'manifesto' claimed that the case of no increase in the demand for consumption goods [following an increase in investment spending] was the one exceptional case Keynes had dealt with... It is ... an obviously special case." On the assumptions here it is the case where the elasticity of the marginal product curve is unitary. Both Keynes and the 'manifesto' authors considered the 'elasticity of supply' to be a determining factor, but neither presents a precise analysis.

\section{Adjustment to demand fluctuations in the Mass Production economy}

Modern economies appear to be subject to strong fluctuations in demand. Indeed, examples of market instability can be found everywhere, although the instability is usually bounded in some way. But there do not appear to be, in the modern world, strong and reliable market-based forces ensuring stability. Investment spending appears to be a major source of demand variation. Yet if the purpose of investment were simply a corrective, moving the actual capital/labor ratio to its optimal level, stabilization would hardly be needed. Such a long-run position would be stationary, or, if the labor force were growing, the economy would expand uniformly. This is the picture presented by neo-classical theory, articulated, for example, by Hayek (1941).

But both Keynes and the older Classicals, especially Ricardo and Marx, offer a different view: investment is the accumulation of capital, a process by which productive power is created, organized and managed. It is driven by the desire for power and wealth, and there is no definable 'optimum'. Investment expands productive power, but does not move the economy towards any definite destination. Given such motivation and the important role of technological innovation, the urge to invest will sometimes be strong and widespread, but at other times weak and uncertain. This may help to explain the need for stabilizing policies, arising from the demand side.

In post-war Mass Production economies (Nell, 1998a), prices do not play an important role in adjustment to changing demand. Employment is much more flexible, and constant returns appear to prevail in the short run; to put it differently, unit costs are broadly constant as employment and output vary over a wide but normal range. Workers need only be semi-skilled and teams can easily be 
broken up and re-formed; processes can be operated at varying levels of intensity in response to variations in demand, and they can easily be shut down and started up. It is likewise easy to lay off and recall workers.

As before we have an aggregate utilization function: here the Mass Production economy will be characterized by a straight line rising from the origin, showing constant marginal returns. As a first approximation Consumption can be identified with wages and salaries, while Investment can be taken as exogenous. As employment rises, the wage bill - and so Consumption spending will rise at a constant rate, namely the normal wage rate. The wage bill - assumed equal to Consumption spending - is represented by a straight line rising to the right from the origin; its angle is the wage rate. Investment spending will be treated as exogenous in the short run, so will be marked off on the vertical axis. Aggregate demand will then be the line $\mathrm{C}+\mathrm{I}$, rising to the right from the I point on the vertical axis; its slope is the wage rate.

Figure 3

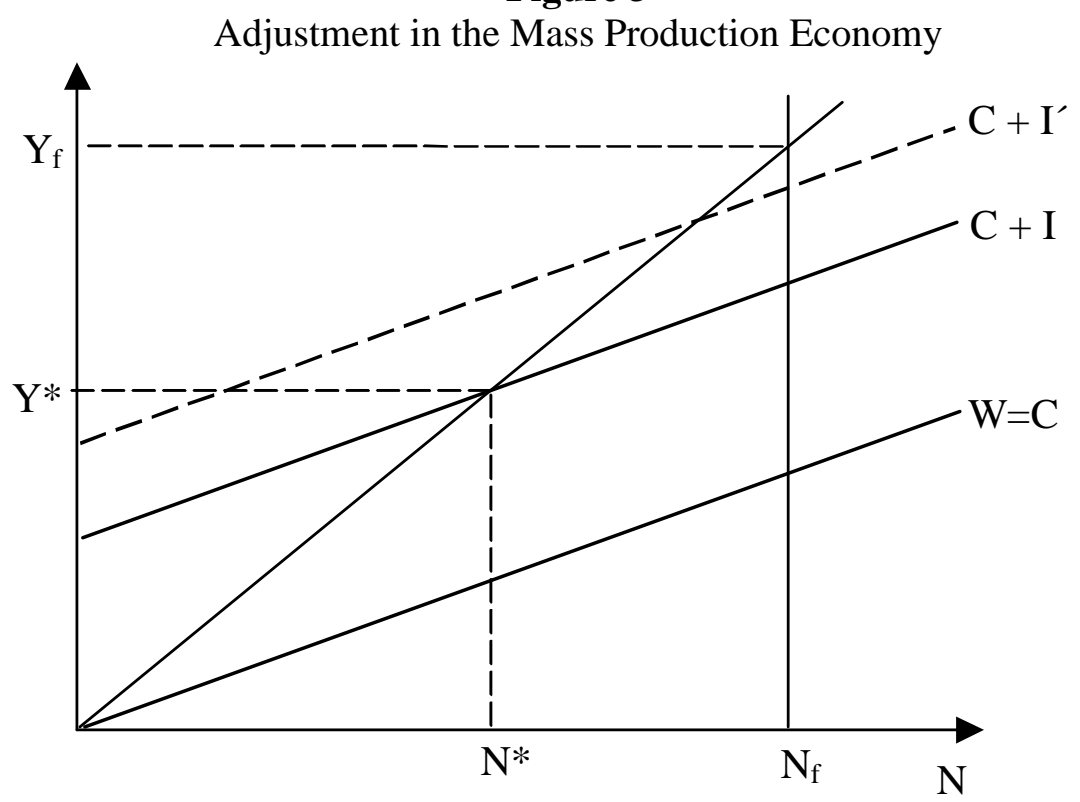

The origin, here and in later diagrams, is the point at which labor cost absorbs all output. Employment in such an economy will depend only on effective demand; there is no marginal productivity 
adjustment. ${ }^{20}$ Output will increase with the amount of labor employed (capacity utilized), with a constant average productivity of labor; all and only wages will be spent on consumption, and all profits will be saved as retained earnings. Investment can be taken as exogenous as a first approximation. ${ }^{21}$ Expenditure is given by the $\mathrm{C}+\mathrm{I}$ line. (This ignores $\mathrm{G}$, government spending, for the moment, although in the modern world it will be much greater than in the earlier forms of the capitalist economy.) But the output function will be a straight line rising from the origin with a slope equal to the average productivity of labor - a. Suppose Investment is exceptionally high; then employment will be increased, and Consumption will also be exceptionally high. Conversely, if Investment is low, employment will be low, and thus so will Consumption. Consumption adjusts in the same direction that Investment moves. ${ }^{22}$ When investment rises, consumption, output and employment also increase in a definite proportion. ${ }^{23}$

Simple as this is, it provides us with a number of powerful insights. Admittedly, they are derived on the basis of very great abstraction, so they cannot be expected to prove literally true - but they may nevertheless give us genuine guidance in investigating the way the world works. For example:

- Investment and profits are equal here; this suggests that we should expect to find them closely correlated in practice - as we do (Nell, 1998a: Ch. 7; Asimakopulos, 1992).

- Investment determines profits here; investment is the driving force. We should expect to find something like this in reality which many studies suggest we do.

- The multiplier here will equal $1 /(1-w / a)$, where $w$ is the real wage, and a the average productivity of labor. That is, the

\footnotetext{
${ }^{20}$ That is, employment is not determined in the labor market. It follows directly from the demand for output, given the output-employment function - as in Kalecki. Hicks, following Keynes, initially modeled effective demand by setting up the IS-LM system together with a labor market and a conventional production function. Later he came to feel that this was a mistake (Hicks, 1977, 1989). But if returns are constant and there is no marginal productivity adjustment, the markup must be explained (cf. Rima, 2003).

${ }^{21}$ On these assumptions Investment determines - and equals - realized Profits. When households save a certain percentage out of wages and salaries the Consumption line will swing below the Wages line - Profits will be reduced. When wealth-owning households (or businesses subsidizing top managers) add to their consumption spending in proportion to the level of activity, this swings the $\mathrm{C}+\mathrm{I}$ line upwards, increasing Profits.

${ }^{22}$ The output multiplier in this simple example will be $1 /(1-\mathrm{wn})$, where $\mathrm{w}$ is the real wage and $\mathrm{n}$ is labor per unit of output.

${ }^{23}$ This is the point that Keynes wrestled with; it shows up in a very simple form here.
} 
multiplier will reflect the distribution of income, and will not be very large. Again this seems plausible.

- Real wages and the level of employment and output are positively related. This can be seen by drawing in a steeper wage line, with the same level of investment. The $\mathrm{C}+\mathrm{I}$ line with then also be steeper; so it will intersect the output line at a higher level of output and employment. In fact most empirical studies of the post-war era do find real wages and employment to be positively related (Nell, 1998b; Blanchard and Fisher, 1989).

- Household savings reduce output, employment and realized profits! (Obviously, qualifications are needed, and it must be remembered that this is a short-run analysis - but the long-run may never come! If this proposition seems hard to accept, think about Japan in the 1990s - and even recently.)

- Unemployment is indicated by marking off the level of full employment on the horizontal axis. It clearly results from deficiency in demand. That is, either investment is too low or wages are too low; which implies that unemployment can be reduced by increasing either.

Finally money: Let household saving increase with the rate of interest (as consumer durable spending declines), while business investment declines as the rate of interest rises (neither influence is likely to be very great). More precisely, when interest is relatively high, businesses are likely to curtail or postpone investment projects, and households may cut back on consumer durables. Thus when interest is high the investment line must shift down to a lower intercept, while the household consumption line will swing down, reducing its angle. When interest rates are relatively low, investment and household spending will be correspondingly higher. Thus we can construct a downward-sloping function (an analogue to the traditional IS) relating the rate of interest, i, to employment, $\mathrm{N}$.

This function will intersect a horizontal line representing the level of the rate of interest as pegged by the Central Bank; this will determine the level of employment. 


\section{Figure 4}

Effects of Interest on Saving and Investment

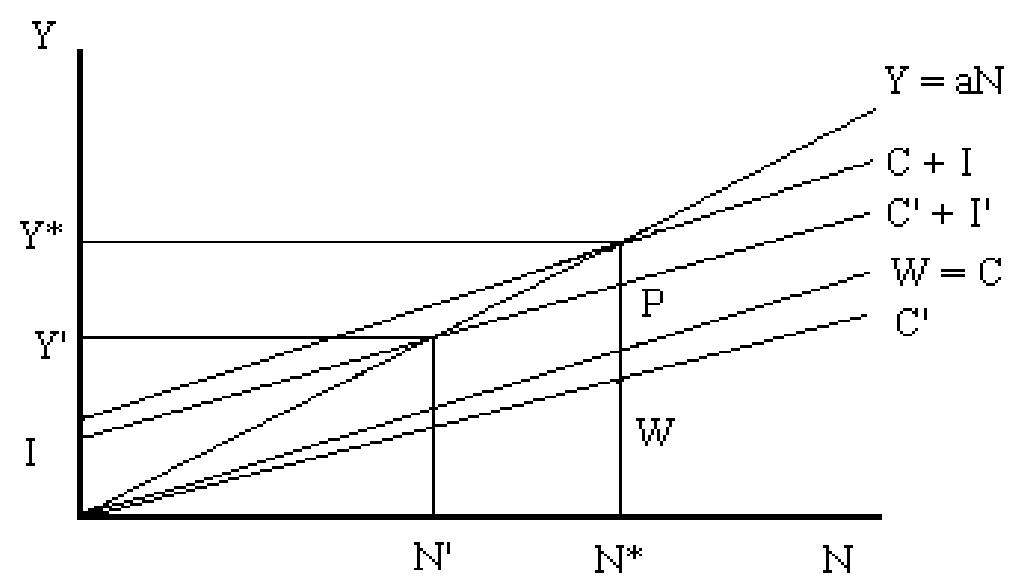

Figure 5

The Central Bank's Interest Rate Determines Employment

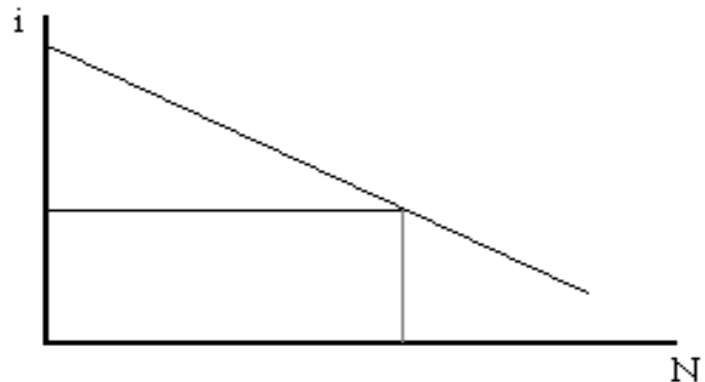

There is no Classical Dichotomy here; monetary and real factors interact. Yet - not so fast! What about Eq. 8c? If we impose this condition, the structure of asset prices will have to adapt to the real conditions of profitability - so the long rate will tend at times to move independently of the short. A form of the dichotomy may re-emerge. But this is another story.

\section{Conclusions}

Keynes accepted the idea that the price mechanism did adjust to ensure that the real wage equaled the marginal productivity of labor. 
He did not, however, explain how this equality was brought about in labor market in which behavior responds to money wages. In his view the equality of the real wage and the marginal product justified calling the position an equilibrium; but his argument shows that there will be a large number (on plausible assumptions, an infinite number) of such positions, besides the full employment level. The way this works can be shown on a diagram in which it is clear that price changes tend to move the system to a profit-maximizing position, for a given level of investment.

But at first sight this appears to be a stabilizing pattern of adjustment. Each position of the economy will be a combination of a level of investment and a level of consumption (equal to the level of the real wage bill), such that higher investment (driving up prices, lowering real wages) would appear to be associated with lower consumption spending. This is stabilizing. When investment falls, for example, prices will fall, and consequently real wages and therefore consumption spending will rise, offsetting the decline in investment.

But such a pattern of adjustment puts the burden on profits; prices would fall in a slump, and firms would have to draw down their reserves. Accordingly firms should seek to develop greater flexibility to allow them to adjust the level of employment to market conditions, laying off and rehiring workers as demand changed. This provides an important incentive to innovate (Nell, 1998a).

Keynes did not examine this. But what he saw is that price adjustment was not working to stabilize the system. On the contrary, fluctuations in investment appeared to set off destabilizing movements. A key point of his lectures was to explain this, showing that investment and consumption moved together, not inversely, thereby increasing volatility. This is a consequence of reducing the rate of diminishing returns, 'flattening' the production function. Furthermore, he argued that investment was the active variable, the causative force, while consumption (and saving) simply re-acted passively. So prices and employment could adjust in such a way that the real wage and the marginal product of labor were brought into equality, thereby maximizing profits, while investment and consumption moved together, rather than inversely, creating 'multiplier-based' volatility in the system. There is no pressure in this system to move to full employment, but each position can reasonably be considered an 'equilibrium'. 


\section{References}

ANDREWS, P. W. S. (1949), Manufacturing Business, London: Macmillan.

(1964), On Competition in Economic Theory, London: Macmillan.

AsIMAKopUlos, T. (1992), "The Determinants of Profits: United States, 1950-1988", in Papadimitriou, D. (ed.) Profits, Deficits and Instability, London, Macmillan.

BlanchaRD, O and FisHER, D. (1989), Lectures on Macroeconomics, Cambridge, Mass: MIT Press

CHICK, V. (1983), Macroeconomics after Keynes, Oxford: Philip Allan.

DAVIDSon, P. (1994), Post-Keynesian Macroeconomic Theory, Cheltenham: Edward Elgar.

Deaton, A. (1992), Understanding Consumption, Oxford: Clarendon Press.

Dunlop, J. T. (1938), "The Movement of Real and Money Wage Rates", Economic Journal, 48 (191), 413-34.

HALl, R. and Hitch, C. (1938), "Price Theory and Business Behavior", in P.W.S. Andrews (ed.), Oxford Studies in the Price Mechanism, Oxford: Oxford University Press.

HAYEK, F. (1932), Monetary Theory and the Trade Cycle (trans. by N. Kaldor and H. Croome), New York: Harcourt Brace. Press.

Hicks, J. R. (1963), A Theory of Wages, $2^{\text {nd }}$ ed, London: Macmillan.

(1977), Economic Perspectives: Further Essays on Money and Growth, Oxford: Clarendon Press.

(1989), A Market Theory of Money, Oxford: Oxford University Press.

HunTER, L. C. (1979), A History of Industrial Power in the US, Vol. 1, Charlottesville: University of Virginia Press.

(1985), A History of Industrial Power in the US, Vol. 2, Charlottesville: University of Virginia Press.

KeYNES, J. M. (1930), A Treatise on Money, London: Macmillan

(1936), The General Theory of Employment, Interest and Money, London: Macmillan.

(1940), How to Pay for the War: A Radical Plan for the Chanceller of the Exchequer ( $1^{\text {st }}$ edition), London: Macmillan.

(1972-9), The Collected Writings of John Maynard Keynes (edited by D. Moggridge), London: Macmillan for the Royal Economic Society.

KLEIN, L. R. (1961), The Keynesian Revolution, London: Macmillan and Co.

Kurz, H. and Salvadori, N. (1995), Theory of Production, Cambridge: Cambridge University Press.

LAIBMAN, D. and Nell, E.J. (1977), "Reswitching, Wicksell Effects and Neoclassical Production Function”, American Economic Review, 63, 100-13.

LavoIE, M. (1994), Foundations of Post-Keynesian Economic Analysis, Cheltenham: Edward Elgar.

Malthus, T. R. (1823), The Measure of Value Stated and Illustrated, with an Application of it to the Alterations in the Value of English Currency Since 1970, London: John Murray. 
Modigliani, F. (1944), "Liquidity Preference and the Theory of Interest and Money", Econometrica, XII (Jan.), 45-88.

NeLl, E. J. (1988), Prosperity and Public Spending, London: Unwin Hyman. (1992), Transformational Growth and Effective Demand, New York: New York University Press.

(1998a), The General Theory of Tranformational Growth, Cambridge: Cambridge University Press.

(1998b) (ed.), Transformational Growth and the Business Cycle, London and New York: Routledge.

Nell, E. J. and DelePlace, G. (1992) (eds.), Money in Motion: The Post-Keynesian and Circulation Approaches, London: MacMillan.

Ricardo, D. (1811), The High Price of Bullion, A Proof of the Depreciation of Bank Notes (enlarged edition), London: John Murray.

RIMA, I. H. (2003), "From Profit margins to Income Distribution: Joan Robinson's Odyssey from Marginal Productivity Theory”, Review of Political Economy, 15 (4), 575-86.

Robertson, D. (1931), “Wage-Grumbles", in Economic Fragments, 42-57, London: P. H. King.

RobINSON, J. (1956), The Accumulation of Capital, London: Macmillan.

RYMES, T. K. (1989) (ed.), Keynes's Lectures, 1932-35: Notes of a Representative Student, Ann Arbor: University of Michigan Press.

TARSHIS, L. (1939), "Changes in Real and Money Wages", Economic Journal, 49 (193), 150-4.

THORnTON, H. (1802), An Enquiry Into the Nature and Effects of the Paper Credit of Great Britain (ed. with introduction by F. A. Hayek), London: George Allen and Unwin, 1939.

\section{Özet}

Toplam talep, istihdam ve marjinal verimlilikte denge: Zenaat ekonomisinde Keynesgil uyum

Keynes-sonrası iktisat akımında yer alanların çoğu, marjinal emek verimliliğinin emek talebini belirlediği savına kuşku ile yaklaşmışlardır. Bu yazarlardan hiçbiri emek arz ve talebinin istihdamı ve reel ücretleri belirlediği görüşünü benimsememiştir. Hepsinin üzerinde mutabık olduğu husus, Keynes'in analizini reel değişkenler üzerine değil, parasal değişkenler üzerine kurduğudur. İşgücü piyasası nominal ücretlerle işliyorsa, şu sorular ortaya çıkacaktır: Reel ücret, marjinal emek verimi ile nasıl uyumlaşmaktadır? Eğer reel ücret, işgücü piyasasında uyumlaşıyorsa, tam istihdam niye sağlanamamaktadır? "Denge"de işsizlik varsa, işsizlik niye yüksek oranlı ve kalıcıdır? Keynes ilgisini toplam talepteki dalgalanmalar üzerine yöneltmiş ve Marshallgil bir ekonominin bu dalgalanmalara nasıl tepki göstereceğini sorgulamıştı. Keynes'in çıkarsamaları, 'çoğaltan'ın azalan verimler altında kâr azamileştirmesine dayanan esnek fiyatlandırma ile tutarlı olduğu biçiminde yorumlanabilir; böylece reel ücret emeğin marjinal verimi ile eşitlenmektedir. Ancak ekonomi yığınsal üretim aşamasına yöneldikçe bu analizin altında yatan Marshallgil perspektifin değiștirilmesi gerekmektedir. Bu makalede ilkin işgücü piyasaları genel kabul gören varsayımlar altında formüle edilmekte, sonra Marshallgil teknoloji ve fiyat mekanizması kabulleri altında ekonominin toplam talepteki değişikliklere nasıl uyum sağlayacağı gösterilmektedir. Daha sonra zenaat teknolojisinden yığınsal üretime geçişin sonuçları üzerinde durulmakta ve son olarak da tam gelişmiş yığınsal üretim koşulları altında Keynesgil sorular incelenmektedir.

Anahtar kelimeler : Keynes, iktisat teorisi, marjinal verimlilik.

JEL sinıflandırmast: B22, E12, E24. 